\title{
Correction: Autoantibodies to citrullinated proteins induce joint pain independent of inflammation via a chemokine- dependent mechanism
}

Wigerblad G, Bas DB, Fernandes-Cerqueira C, et al. Autoantibodies to citrullinated proteins induce joint pain independent of inflammation via a chemokine-dependent mechanism. Ann of Rheum Dis 2016;75:730-. doi:10.1136/annrheumdis-2015-208094.

The specificity of the human monoclonal antibodies B02 and D10 used in functional experiments in this article, originally described as high affinity ACPAs, has been re-evaluated. In accordance with data that were made available to us (Ge et al., Arthritis Rheumatol, 2019; 71:210-221, and others), the two monoclonal antibodies used lack specific binding to citrullinated peptides in surface plasmon resonance (SPR) and other assays as described in the retraction note to Journal of Experimental Medicine (Amara et al Retraction J. Exp Med 2019; 216:245). As such the functional results reported for these monoclonal antibodies cannot be attributed to reactivity against citrullinated proteins and/or peptides, but are due to other yet unknown mechanisms. Thus, the pathogenetic implications derived from these experiments cannot be maintained as stated. Specifically, this relates to findings presented in figure 2 A-D and 6 B-E.

Note that in: Figure 2A the table ranking reactivity against citrullinated proteins and/or peptides is based on the original ELISA from the retracted Amara et al Retraction J. Exp Med $2019 ; 216: 245$; the results from this ELISA were not reproducible in other assays.

In light of the lack of specificity of these monoclonal antibodies, the functional results observed in Figures 2C-D (reduction in withdrawal thresholds after injection of B02 and D10 monoclonal antibodies); 6B-C (B02/D10-induced mechanical hypersensitivity described as reduction in mechanical hypersensitivity and algesic index); and 6D-E (B02/D10-induced thermal hypersensitivity described as a change in withdrawal latency), confirming the suggested CXCL1 mediation of hypersensitivity using the CXCL1/XCL2 antagonist reparixin, cannot be attributed to reactivity against citrullinated proteins and/or peptides and must have been due to other, hitherto unknown mechanisms.

Since the monoclonal antibodies were used to confirm and expand the data obtained with polyclonal antibody preparations, the remaining conclusions in the paper rely on the data from the polyclonal IgG antibodies purified by affinity chromatography on CCP2-linked Sepharose columns. Although the pronociceptive effects in mice were induced by the CCP2column eluate IgG (endotoxin free) and not the flow through fractions, also these results have to be interpreted with caution and we conclude that the pathogenetic specificity of these observations and the detailed pronociceptive mechanisms remain to be elucidated. Consequently, we feel that the title on page 730 should be corrected from

"Autoantibodies to citrullinated proteins induce joint pain independent of inflammation via a chemokine-dependent mechanism" to: "Autoantibodies to citrullinated proteins may induce joint pain independent of inflammation".

We specifically apologise for the delays from our side in communicating the information in this correction note to the readership of ARD.

\section{6 \\ OPEN ACCESS}

\begin{abstract}
Open access This is an open access article distributed in accordance with the Creative Commons Attribution Non Commercial (CC BY-NC 4.0) license, which permits others to distribute, remix, adapt, build upon this work noncommercially, and license their derivative works on different terms, provided the original work is properly cited, appropriate credit is given, any changes made indicated, and the use is non-commercial. See: http://creativecommons.org/licenses/by-nc/ 4.0\%.

(c) Author(s) (or their employer(s)) 2019. Re-use permitted under CC BY-NC. No commercial re-use. See rights and permissions. Published by BMJ.
\end{abstract}

Ann Rheum Dis 2019;78:865. doi:10.1136/annrheumdis-2015-208094corr1

Check for updates 